\title{
PHALAENOPSIS ARUNACHALENSIS SP. NOV. (ORCHIDACEAE: EPIDENDROIDEAE: AERIDINAE) - A NEW EPIPHYTIC ORCHID FROM ARUNACHAL PRADESH, NORTHEAST INDIA
}

\author{
KhyanjeEt Gogol ${ }^{1,3}$ \& KoJ Rinya ${ }^{2}$ \\ ${ }^{1}$ The Orchid Society of Eastern Himalaya (TOSEHIM), Regional Orchids Germplasm Conservation \& \\ Propagation Centre (Assam Circle), Daisa Bordoloi Nagar, Talap, Tinsukia 786 156, Assam, India \\ ${ }^{2}$ Divisional Forest Officer, Hapoli Forest Division, Lower Subansiri District, Arunachal Pradesh, India \\ ${ }^{3}$ Author for correspondence: khyanjeetgogoi@gmail.com
}

\begin{abstract}
A new epiphytic Phalaenopsis is described from tropical evergreen forests of Ziro Valley in Arunachal Pradesh, India, and illustrated with colored photos. It is allied to the similarly colored P. taenialis (Lindl.) Christenson \& Pradhan in having non-deciduous leaves, larger perianth segments, the shorter and convex (not flat) lip mid-lobe, and the yellowish-green (not purplish) spur. The new species is morphologically most similar to $P$. honghenensis from China, but differs most easily by the light pinkish flowers versus bronzy green to brownish flowers of the latter species. A detailed description with corresponding color photos and information on the habitat is provided. The voucher specimens have been deposited at the Herbarium of the Orchid Research Centre Tippi, Arunachal Pradesh, and the Herbarium of The Orchid Society of Eastern Himalaya (TOSEHIM), Regional Orchid Germplasm Conservation and Propagation Centre (Assam Circle), Assam.
\end{abstract}

Key Words: Flora of India, new Phalaenopsis, Phalaenopsis honghenensis, Phalaenopsis subgen. Aphyllae, Phalaenopsis taenialis

Introduction. The genus Phalaenopsis Blume was first described by Carl Ludwig Blume in 1825. The genus is represented by a total of 97 species and is widely distributed across Southeast Asia (South India, Sri Lanka, southern China to Taiwan, Indonesia, Thailand, Myanmar, Malaysia, the Philippines, Papua New Guinea) and northern Australia (Govaerts et al. 2020). Whereas Sweet (1980) initially listed 47 species for the genus and Christenson (2001) listed 62 entities. In India the genus is represented by 12 species (Misra 2019) distributed throughout the Himalayas, Peninsular India and Andaman and Nicobar islands and only four of them were recognized in Arunachal Pradesh (Rao 2010) viz. Phalaenopsis deliciosa Rchb.f., P. mannii Rchb.f., P. lobbii (Rchb.f.) Sweet, and $P$. taenialis (Lindl.) Christenson \& Pradhan. So far, there have been a much of complexity associated with the subgen. Aphyllae where our new species belongs and has been dealt by Dalström et al. (2010) where much of the problems involving $P$. taenialis complex were largely resolved.

On 15 October, 2019, during a field trip to the forested area of Ziro Valley of Lower Subansiri district of Arunachal Pradesh, the first author collected an epiphytic orchid. It was subsequently planted along an orchid trail located in the Tale Wildlife Sanctuary, Ziro Valley of Arunachal Pradesh, and flowered under observation in March, 2020. Comparing it with the available literature (Hooker 1890, 1894, King \& Pantling 1898, Pradhan 1979, Chowdhery 1998, Pearce \& Cribb 2002, Lucksom 2007, Chen et al. 2009, Rao 2010, Dalström \& Ormerod 2010, Dalström et al. 2010, Hegde 2017, Swami 2017, Gogoi 2019, Gruss 2020) and critical examination of herbarium specimens deposited in ASSAM, ARUN, CAL, as well as with type images present in K, E and $\mathrm{PE}$, it was confirmed that this orchid represented an hitherto undescribed Phalaenopsis species. Hence, it is described below as new.

\section{TAXONOMIC TREATMENT}

Phalaenopsis arunachalensis K.Gogoi \& Rinya sp. nov.

TYPE: India. Arunachal Pradesh: Lower Subansiri, Ziro, 1400 m, 16 October 2019, fl. 15 April 2020, K. 
Gogoi and K. Rinya 00809 (Holotype: OHT; Isotypes: ASSAM, TOSEHIM). (Fig. 1-3).

Diagnosis: Phalaenopsis arunachalensis differs from the similarly colored P. taenialis (Lindl.) Christenson \& Pradhan in having non-deciduous leaves, larger perianth segments, shorter and convex (not flat) lip mid-lobe and yellowish-green (not purplish) spur. The new species also differs from the similarly shaped $P$. honghenensis F.Y.Liu by the pinkish flowers versus bronzy green or brownish flowers in the latter species. The differences between $P$. arunachalensis and $P$. taenialis are shown in Table 1.

Herb epiphytic. Roots flattened, minutely warty, young roots silvery with green and maroon root caps. Stems to $1 \mathrm{~cm}, 2$ or 3-leaved. Leaves obliquely elliptic, 5-10 $\times 2.5-3.5 \mathrm{~cm}$, acute at apex, sheathing bases persistent, spotted purple-red. Inflorescence suberect to pendent, racemose, to $21.5 \mathrm{~cm}$, laxly 5-6-flowered; peduncle $c a .10 \mathrm{~cm}$ long; rachis $c a$. $11.5 \mathrm{~cm}$ long; floral bracts ovate, to $6 \mathrm{~mm}$. Flowers to $3.0-3.2 \mathrm{~cm}$ across, sepals and petals rose-pink, lip purple; pedicel and ovary $3.2-3.5 \mathrm{~cm}$. Dorsal sepal oblong-elliptic, $1.5-1.6 \times 0.8 \mathrm{~cm}$, obtuse. Lateral sepals obliquely elliptic-ovate, $c a .1 .5 \times 0.9 \mathrm{~cm}$, obtuse. Petals spathulate, ca. $1.5 \times 0.8 \mathrm{~cm}$, obtuse Lip minutely spurred, trilobed; lateral lobes oblong, ca. $9 \times 2 \mathrm{~mm}$, obliquely truncate; mid-lobe oblong, ca. $9 \times 4 \mathrm{~mm}$, tapered at both ends, apex obtuse. Spur cylindric-conical, $2 \mathrm{~mm}$ long. Callus biseriate: posterior callus fleshy, bifid, terminating at base of mid-lobe; anterior callus plate like, bifid, extending beyond base of mid-lobe. Column to $9 \mathrm{~mm}$ long, stout, conspicuously dilated to either side of stigma, foot 2-3 mm. Pollinia 4, sub-globose, yellow. Seed pods and seeds not seen.

Examined material: India. Arunachal Pradesh: forested area of Ziro Valley of lower Subansiri district, 16 October 2019, fl. 15 April 2020 in the Tale Wildlife Sanctuary, K. Gogoi and K. Rinya 00809.

Flowering PERIOD: March to April.

НАвітAт: On tree trunks in sub-tropical evergreen forest at 1200-1400 m in Ziro, Arunachal Pradesh.

Distribution: India (Ziro, Arunachal Pradesh).

Eтymology: The specific epithet refers to the state of Arunachal Pradesh, in Northeast India, from where the new species was collected.

TABLE 1. Diagnostic features of Phalaenopsis arunachalensis and P. taenialis.

\begin{tabular}{|c|c|c|}
\hline & P. arunachalensis & P. taenialis \\
\hline Leaves & $\begin{array}{l}\text { Persistent at anthesis, obliquely elliptic, } 5-10 \times 2.5- \\
3.5 \mathrm{~cm} \text {, acute at apex. }\end{array}$ & $\begin{array}{l}\text { Deciduous at anthesis, narrowly elliptic-oblong, } 2-4 \times \\
1.5-1.8 \mathrm{~cm} \text {, acute, tapering to the sessile base. }\end{array}$ \\
\hline Inflorescence & $\begin{array}{l}\text { Erect to suberect, unbranched, up to } 21.5 \mathrm{~cm} \text { long, } \\
5-6 \text { flowered. }\end{array}$ & $\begin{array}{l}\text { Erect to pendant, unbranched, 5-12 cm long, 4-8 } \\
\text { flowered. }\end{array}$ \\
\hline Floral bracts & Ovate. & Triangular. \\
\hline Flowers & $\begin{array}{l}3.0-3.2 \mathrm{~cm} \text { across, sepals and petals rose-pink, lip } \\
\text { purple. }\end{array}$ & $2.0-2.5 \mathrm{~cm}$ across, pale pink to rose, lip rose-purple. \\
\hline Dorsal sepal & Oblong-elliptic, ca. $2 \times 0.8 \mathrm{~cm}$, apex obtuse. & Ovate, $1.1 \times 0.35-0.40 \mathrm{~cm}$, apex round. \\
\hline Lateral sepals & Obliquely elliptic-ovate, ca. $1.5 \times 0.9 \mathrm{~cm}$, base obtuse. & $\begin{array}{l}\text { Obliquely elliptic-ovate, obtuse, } 1.0-1.2 \times 0.30-0.35 \mathrm{~cm} \text {, } \\
\text { base cuneate. }\end{array}$ \\
\hline Petals & Spatulate, ca. $1.5 \times 0.8 \mathrm{~cm}$, apex obtuse. & Ovate, $1.1 \times 0.35-0.40 \mathrm{~cm}$, apex round. \\
\hline Lip & $\begin{array}{l}\text { Lateral lobes ca. } 9 \times 2 \mathrm{~mm} \text {, obliquely truncate; mid- } \\
\text { lobe oblong, ca. } 9 \times 4 \mathrm{~mm} \text {, tapered at both ends, apex } \\
\text { obtuse. Spur nipple like, } 2 \mathrm{~mm} \text {. }\end{array}$ & $\begin{array}{l}\text { Lateral lobes } 6 \times 1.5 \mathrm{~mm} \text {, obtuse; mid-lobe, flat, } \\
\text { spatulate, } 10.0-11.5 \times 3.5-4.0 \mathrm{~mm} \text { the backwall of the } \\
\text { spur. }\end{array}$ \\
\hline Callus & $\begin{array}{l}\text { Posterior callus fleshy, bifid, terminating at base of } \\
\text { mid-lobe; anterior callus plate like, bifid, extending } \\
\text { beyond base of mid-lobe. }\end{array}$ & $\begin{array}{l}\text { Posterior callus fleshy, bidentate, on back wall of spur; } \\
\text { anterior callus ligulate, deeply bifid, attached to front wall } \\
\text { at base of mid-lobe. }\end{array}$ \\
\hline Column & $\begin{array}{l}\text { Up to } 9 \mathrm{~mm} \text {, stout, conspicuously dilated to either side } \\
\text { of stigma, foot } 2-3 \mathrm{~mm} \text {. }\end{array}$ & $\begin{array}{l}\text { 4-6 mm, strongly dilated at the middle to either side of } \\
\text { the anther; pedicel and ovary } 14-16 \mathrm{~mm} \text { long. }\end{array}$ \\
\hline Flowering time & March - April. & May. \\
\hline
\end{tabular}




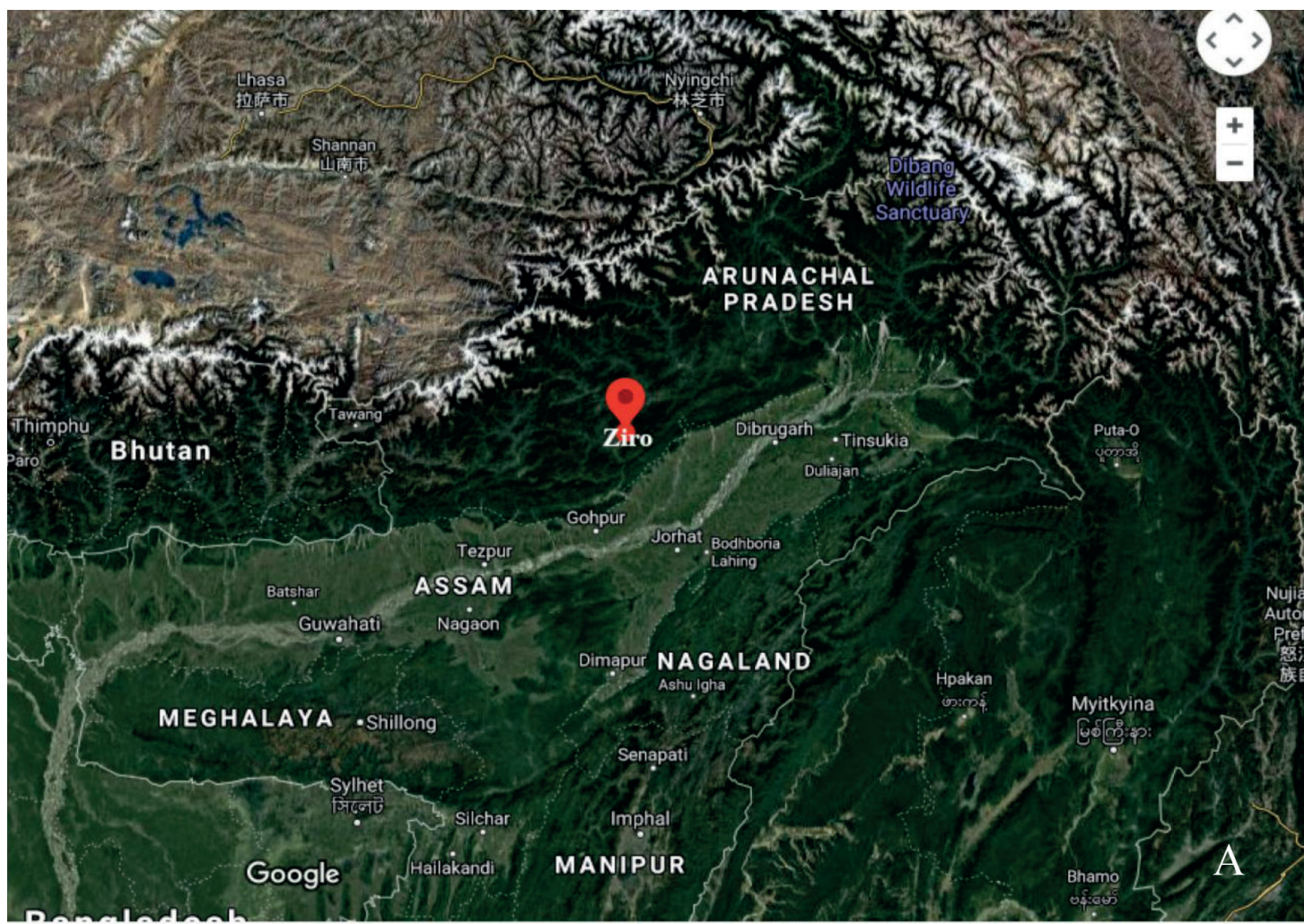

Imagery \&2020 TerraMetrics, Map data 2020 Google $100 \mathrm{~km}$

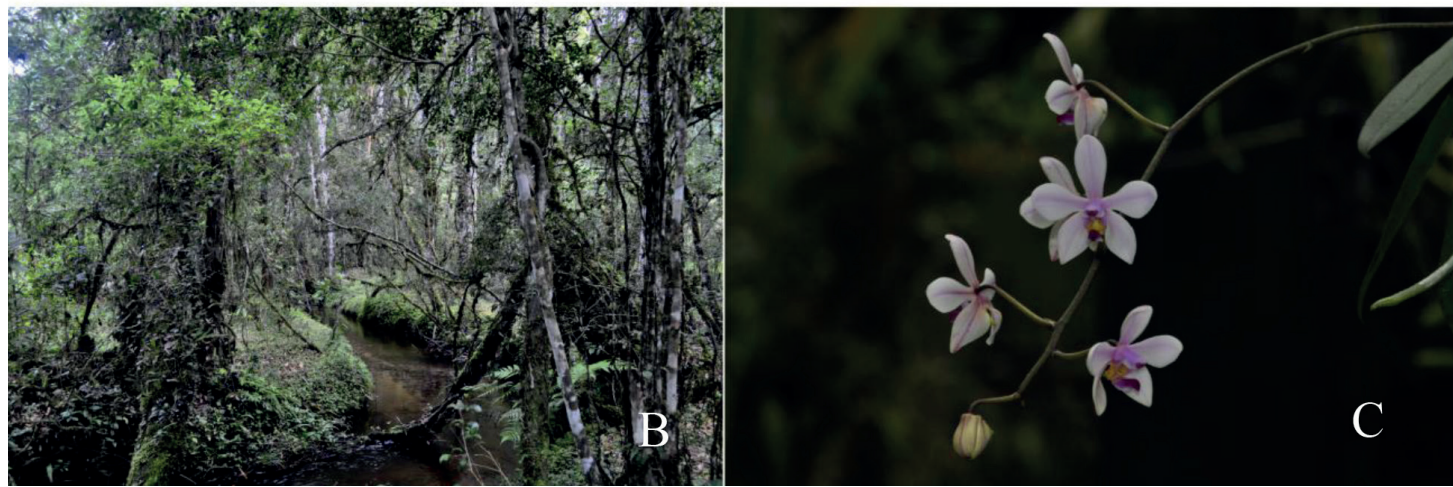

FIGURE 1. A. Distribution map of Phalaenopsis arunachalensis. B. Natural habitat of P. arunachalensis. C. Phalaenopsis arunachalensis in natural habitat showing close up of inflorescence. Photos by K. Gogoi.

ACKnOwledgements. The authors are grateful to Dr. Pankaj Kumar, Kadoorie Farm and Botanic Garden (KFBG) Corporation, Lam Kam Road, Tai Po, New Territories, Hong Kong S.A.R., China; Olaf Gruss, In der Au 48, 83224, Grassau, Germany, and Stig Dalström, Lankester Botanical Garden, University of Costa Rica, Cartago, Costa Rica for providing literature and valuable suggestions for the identity of the species. The authors are also thankful to Dipanker Bora, Rajib Gandhi University, Arunachal Pradesh and
Department of Environment and Forest, Government of Arunachal Pradesh (India) for their cooperation.

\section{LITERATURE CITED}

Blume, C. L. (1825). Phalaenopsis. In: C. L. Blume (ed.), Bijdragen tot de Flora van nederlandsch Indië, 7de Stuk (p. 294). Batavia: Ter Lands Drukkerij.

Chen, X. Q., Liu, Z. J., Zhu, G. H., Lang, K. Y., Ji, Z. H., Luo, Y. B., Jin, X. B., Cribb, P. J., Wood, J. J., Gale, S. 


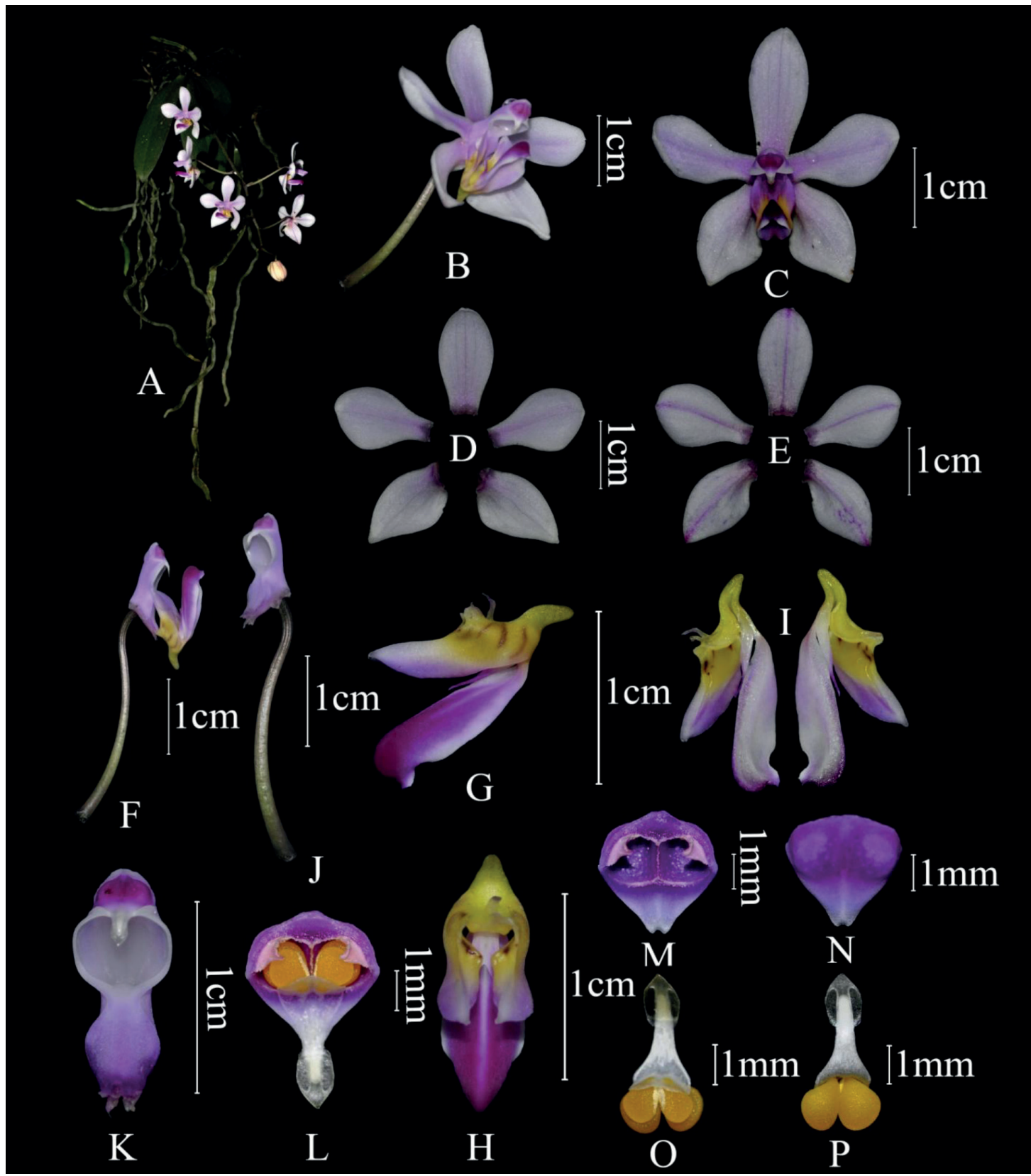

Figure 2. Phalaenopsis arunachalensis. A. Habit. B. Flower, side view. C. Flower, ventral view. D. Perianth, ventral view.

E. Perianth, dorsal view. F. Lip with ovary and column. G. Lip, side view. H. Lip, ventral view. I. Lip, longitudinal section. J. Ovary with pedicel and column. K. Column, front view. L. Anther cap with pollinia, ventral view. M. Anther cap, ventral view. N. Anther cap, dorsal view. O. Pollinarium, ventral view. P. Pollinarium, dorsal view. Photos by K. Gogoi.

Right, Figure 3. Phalaenopsis arunachalensis. A. Habit. B. Flower, side view. C. Flower, ventral view. D. Perianth, ventral view. E. Perianth, dorsal view. F. Lip with ovary and column. G. Lip, side view. H. Lip, ventral view. I. Ovary with pedicel and column. J. Column, front view. K. Anther cap with pollinia, ventral view. L. Anther cap, ventral view. M. Anther cap, dorsal view. N. Pollinarium, ventral view. O. Pollinarium, dorsal view. Drawing by K. Gogoi. 


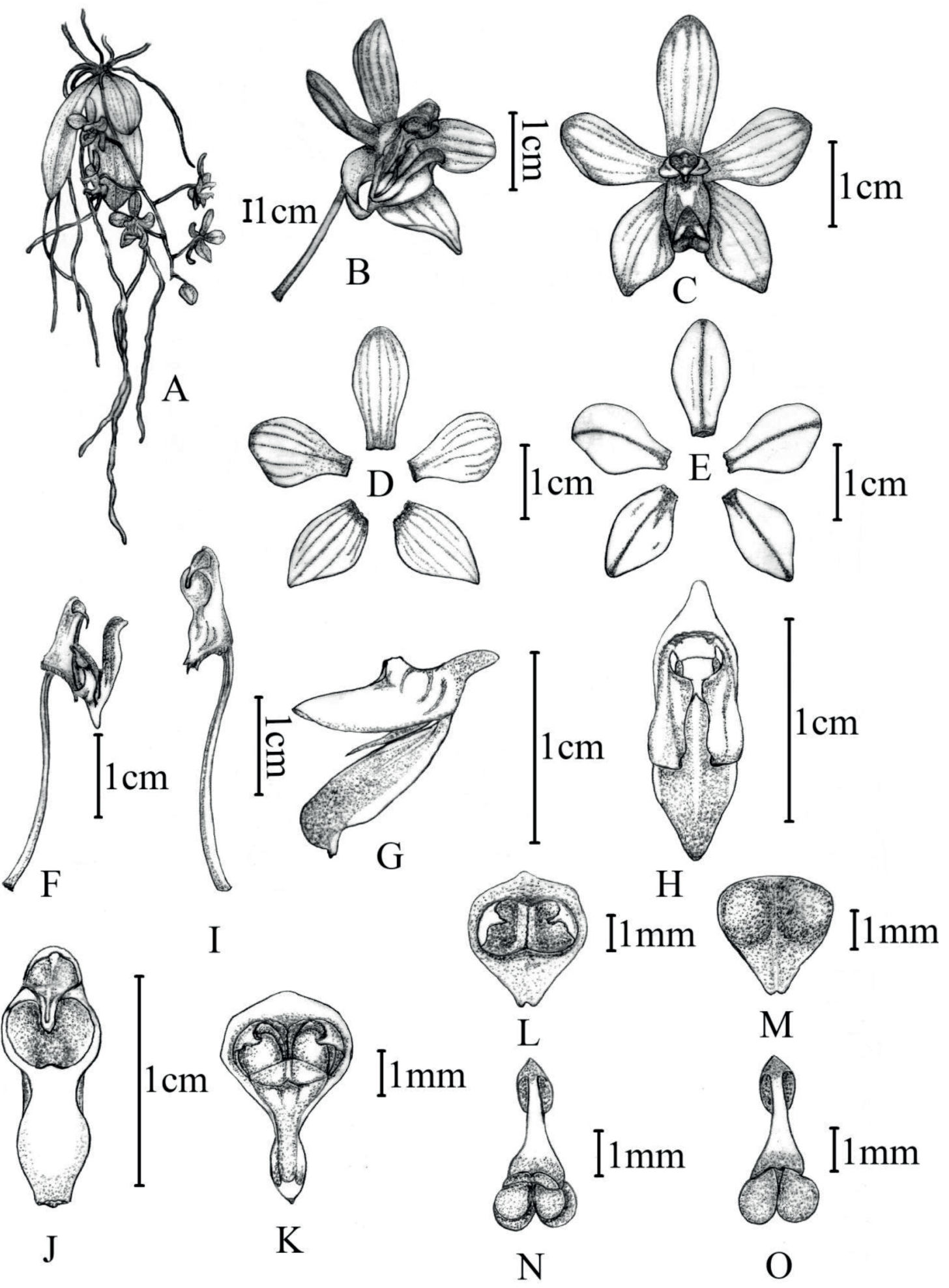


W., Ormerod, P., Vermeulen, J. J., Wood, H. P., Claton, D. \& Bell, A. (2009). Orchidaceae. In: Z. Y. Wu, P. H. Raven \& D. Y. Hong (eds), Flora of China, volume 25 (pp. 1-506). St. Louis: Missouri Botanical Garden Press.

Chowdhery, H. J. (1998). Orchid Flora of Arunachal Pradesh. Dehra Dun, India: Bishen Singh Mahendra Pal Singh.

Christenson, E. A. (2001). Phalaenopsis. Portland, Oregon: Timber Press.

Dalström, S. \& Ormerod, P. (2010) Green Phalaenopsis. Orchids, 79 (12), 706-708.

Dalström, S., Gyeltshen, N. G. \& Höijer T. H. (2010). Phalaenopsis taenialis, a case of split personality. Orchids, 79(8), 468-471.

Gogoi, K. (2019). Orchids of Assam - A Pictorial Guide. Dibrugarh, Assam: Dibrugarh University.

Gruss, O. (2020). Phalaenopsis wilsonii. Phalaenopsis, $30(2), 6-26$.

Hegde, S. N., revised by Tam, N., Tsering, J., \& Apang, O. (2017). Orchids of Arunachal Pradesh. Itanagar, India: Department of Environment and Forest, Govt. of Arunachal Pradesh.

Hooker, J. D. (1890). Order CXLVIII Orchideæ. In: J. D. Hooker (ed), Flora of British India, volume V, Chenopodiacece to Orchidece (pp. 667-858). London: L. Reeve and Co.

Hooker, J. D. (1894). Order CXLVIII. Orchideæ. In: J. D. Hooker (ed), Flora of British India, volume VI,
Orchidea to Cyperacea (pp. 1-198). London: L. Reeve and Co.

King, G. \& Pantling, R. (1898). The orchids of the Sikkim Himalayas. Annals of the Royal Botanical Garden Calcutta, 8, 1-342, tt. 1-448.

Lucksom, S. Z. (2007). The Orchids of Sikkim and North East Himalaya. Siliguri : S. Z. Lucksom.

Misra, S. (2019). Orchids of India- A hand book. Dehra Dun, India: Bishen Singh Mahendra Pal Singh.

Pearce, N. R. \& Cribb, P. J. (2002). Orchids of Bhutan: Flora of Bhutan. Vol. 3, No. 3. Edinburg: Royal Botanical Garden Edinburg.

Pradhan, U. C. (1979). Indian Orchids Guide to Identification and Culture. Vol. II. Faridabad, India: Thomson Prass.

Rao, A. N. (2010). Orchid flora of Arunachal Pradesh - an update. Bulletin of Arunachal Forest Research, 26 (12), 82-110

Swami, N. (2017). Orchids of Ziro. India: Thomson Press India Ltd.

Sweet, H. R. (1980). The genus Phalaenopsis. The Orchid Digest, Orchids of the world Volume 1. California: Pomona.

Govaerts, R., Bernet, P., Kratochvil, K., Gerlach, G., Carr, G., Alrich, P., Pridgeon, A. M., Pfahl, J., Campacci, M A., Holland, D., Baptista, Tigges, H., Shaw, J., Cribb, P., George, A., Kreuz, K. \& Wood, J. (2020). World checklist of selected plant families. Facilitated by the Royal Botanic Gardens, Kew. Retrieved from http:// wcsp.science.kew.org [accesed on 15 April 2020]. 